Article

\title{
Key Features of E-Tailer Shops in Adaptation to Cross-Border E-Commerce in the EU
}

\author{
Artur Strzelecki 1 \\ Department of Informatics, University of Economics in Katowice, 40-287 Katowice, Poland; \\ artur.strzelecki@ue.katowice.pl
}

Received: 21 February 2019; Accepted: 11 March 2019; Published: 15 March 2019

\begin{abstract}
This study attempts to determine the most important features of e-tailer shops regarding their adaptation of cross-border e-commerce. The open market in the European Union (EU) encourages consumers to make cross-border purchases. The aim of the paper is to determine which features are important for customers and should therefore be taken into consideration by e-tailers when providing their services. The paper is based on a study conducted in Poland. Polish e-commerce stores are broadening their market opportunities to other European countries. The study included 30 Polish e-tailers from the household goods sector (e.g., TVs, computers, washing machines, etc.). The theory is grounded in online shopping and website analysis. The author found that not all key features of e-tailer shops in the observed industry sector were developed in websites; some online shops lacked these features. A limitation is that the observation was conducted in only one country and industry sector. However, the sector studied represents the majority of online shops and the industry was the subject of the study. Research shows which features of online shops are important for customers who make cross-border e-commerce. Originality and contribution are based on the identification, analysis, and results of the features to adjust in the European cross-border e-commerce.
\end{abstract}

Keywords: e-commerce; cross-border e-commerce; online shopping

\section{Introduction}

Cross-border e-commerce is a type of trade between retailers and customers in which retailers sell goods online using an e-commerce store. Retailers selling online are called e-tailers. Customers purchase goods using a web browser on their computers or mobile devices. As the e-tailers and customers are from two different countries, the orders need to be sent from one country to another country, thus crossing a border.

Ubiquitous globalization [1] and digital revolution affect economic processes, including foreign trade. Cross-border e-commerce is observed all over the world, e.g., between strong economies in North America [2], Asia [3-8], and Europe [9]. Theoretically, the openness of markets in the European Union (EU) [10] and the development of the Internet [11] enabling online transactions have led to the emergence of a new model of foreign trade [12]: Cross-border e-commerce [13]. According to the EU's forecasts, the development of the cross-border e-commerce model may bring the European economy 415 billion EUR per annum [14] and lead to the creation of hundreds of thousands of new jobs. According to the "European B2C E-commerce report" [15], electronic trade in the EU in 2015 amounted to 407.4 billion EUR. Therefore, both an analysis of cross-border e-commerce using online shops and an evaluation of the possibilities to increase the level of adaptation of e-commerce to cross-border trade seem worthy of investigation.

Cross-border e-commerce has a positive impact [16] on the scale of economic convergence; however, its pace of growth could be faster. The main obstacle of conventional cross-border retailing is 
geographical distance. Geographical borders are of less significance on the Internet but are replaced by other issues. Those frequently mentioned and described in recent reports $[17,18]$ are as follows:

- Language: This is a natural barrier, however, a good command of English usually enables making purchases almost anywhere around the world.

- High costs of international shipments: The significance of this barrier has decreased gradually due to the increasing competition between courier companies, resulting in lower shipment prices in the EU.

- Legal regulations: Problems connected with this barrier have been noted by the EU authorities, resulting in recently adopted EU Directives unifying consumer law across the member states [14] that have decreased the significance of barriers related to legal regulations.

- Payments: Similar to shipping costs, this barrier is becoming less significant as a result of the competition, as well as the development of the international payments market in the EU.

The novelty of this research is that different and independent factors in e-tailer shops are observed together as key factors that help attract customers from abroad. The research gap identified in the literature shows that no such approach has yet been adopted in studying e-tailer shops. The author studied e-commerce in Poland because it is an EU member state and it is possible to observe whether e-tailer shops are attractive for customers from other member states. The novelty here is that cross-border e-commerce can be described in specific circumstances, i.e., a group of e-tailer shops operating in the same economic environment.

The theory is grounded in online shopping, website analysis, and recent studies about different aspects of cross-border e-commerce. The analysis was conducted on 30 Polish e-tailers selling household goods. The objectives of this paper are: To study the current issues relating to cross-border commerce, primarily using data from the European Commission's reports; and to conduct research on how cross-border e-commerce works in the household-goods sector in Poland. The rest of this paper is organized as follows: The next section provides a review of the relevant literature and the context of the study. Then, the study setup is described and, following this, the results are presented and discussed. Finally, conclusions are drawn.

\section{Literature Review}

This section contains literature review. It is divided into four areas: Online resolution systems, models of cross-border e-commerce, e-commerce website features and context of the study. The first three subsections are based on scientific literature, the fourth one is on industry reports mainly ordered by the European Commission.

\subsection{Online Resolution Systems}

Several researchers have made contributions to the field of B2C transactions from the legal perspective $[19,20]$. To this area belongs online dispute resolution (ODR) [21]. ODR is, in its simplest terms, an alternative dispute resolution transferred to the online environment. ODR serves as a protection for weaker contract parties like consumers [22]. Stylianou [23] noted that there is a growing need for new jurisdictional rules and more effective means of cross-border dispute resolution. However, the novel online environment has led to the evolution of traditional dispute resolution, including practices covering negotiation, mediation, and arbitration. Edwards and Wilson [24], using Eurobarometer data [25], showed that $41 \%$ of people who launched a formal complaint concerning cross-border purchases were not satisfied with the way their complaint was handled. Rather than going to the courts or elsewhere for settlement, most dissatisfied consumers took no further action, and only $6 \%$ brought the matter to an arbitration, mediation and conciliation body. Other studies have described challenges in designing a global consumer ODR system [26] and showed that effective dispute settlement is one way to enhance consumer confidence in cross-border purchases made via the Internet [27]. However, Cortés and de la Rosa [28] argued that in low-value e-commerce cross-border 
transactions, the most effective consumer protection policy could not be based on national laws and domestic courts. Lin et al. [29] showed that swift action following a dispute in cross-border e-commerce could help restore trust in the e-tailer.

\subsection{Models of Cross-Border E-Commerce}

Another area of research concerns the development of cross-border B2B e-commerce. A model of cross-border B2B e-commerce in Iran was developed covering three key areas: Messaging, business process, and content [30]. Tan and Thoen [31] designed a model of trust in e-commerce, focusing on two e-commerce activities that require trust: Electronic payment, and cross-border electronic retailing. They showed that with the model these two activities required two different types of trust and that completely different services are needed to create these types of trust. Other research has suggested that cultural value depiction is not very strong in cross-border markets and a certain degree of "cultural alienation" takes place [32]. To engage better with customers and reach better cultural congruency, companies need to work harder on developing culturally adapted websites [33].

\subsection{E-Commerce Website Features}

Another branch of research has focused on the features of e-commerce websites [34]. Curty and Zang [35] conducted a historical analysis of the top five e-commerce companies since their websites were established and were able to identify and classify a total of 174 emerging technical features. Key features of cross-border e-commerce websites discussed in the literature include the use of the shop-bots and security, especially during the payment process. Regarding shop-bots, Tang et al. [36] examined the impact of changes in shop-bot use over time on pricing behavior in the Internet book market. They found that a $1 \%$ increase in shop-bot use was correlated with 0.41 U.S. dollars decrease in price levels and a 1.1\% decrease in price dispersion. Dulleck et al. [37] conducted a study on the behavior of buyers on an Austrian price comparison website. They found that consumer behavior could be described as a two-stage procedure: Selecting a group of offers based on the price only. Then, in the buying decision, consumers trade-off a lower price with a higher reliability of the retailer. Ellison and Ellison [38] examined the competition between groups of e-tailers operating in an environment where a price search engine played a dominant role. They found that advances in search technology were accompanied with investments by e-tailers in search traffic from shop-bots.

McCole et al. [39] noted that in the context of B2C relationships, security during an online purchase was important for the consumer to accept any risk associated with a transaction. Kim et al. [40] examined issues related to e-payment security from the viewpoint of customers and found that perceptions of the security of e-payment systems have become a major factor in the evolution of e-commerce in markets. Payment systems are often considered difficult in e-commerce, especially in the context of cross-border online shopping. There are different kinds of payment systems available for online sellers. These include the credit, debit, and virtual cards, as well as new technologies like e-wallets, e-cash, mobile payment, e-checks, and cash on delivery [41]. To promote the development of cross-border online shopping, it is necessary to provide customers with a safe payment environment and give support to international bank clearing [42]. Strzelecki and Rizun [43] analyzed four factors in the European environment that can ensure safe online shopping for consumers: Terms of service adjusted to the GDPR, usage of well-known payment methods, presence in local price comparison engines, and SSL certificates

Martens [44], when comparing results from three studies on online cross-border trade, found a significant reduction in distance-related trade costs. One of these studies used data from the EU e-commerce consumer survey to construct a dataset of online B2C domestic and cross-border retailing of goods between the $27 \mathrm{EU}$ member states. In line with other studies, results showed a significant reduction in geographical distance-related retailing costs when EU consumers moved from offline to online trade [13]. Kawa [45], however, proposed the development of a model facilitating cooperation between online shops dealing with cross-border trade because of difficulties in delivering goods to 
distant places or the relatively long time and high cost of providing the purchased product. Based on this part of the review, two research questions are posed:

RQ1. Which key features are crucial for cross-border e-commerce?

RQ2. How often do e-tailers use the identified features?

\subsection{Context of the Study}

The context of the study relates to various reports, mainly made by the European Commission's in-house science services. These reports provide data collected from several surveys [46]. In 2016, about two-thirds of Internet users in the EU shopped online, although only 32\% shopped online cross-border [47]. Cross-border e-commerce development depends on the globalization of the world economy. The globalization of the world economy is characterized by a significant increase in the interconnections, collaborations, and interdependencies between countries resulting from the tendency of the economic objectives and interests to exceed national borders [48]. Another significant influence on the development of cross-border online shopping is financial integration [49]. Research on cross-border e-commerce by Van Heel et al. [50], showed a rising trend for online transactions with foreign online shops.

In 2016, 32\% of online shoppers bought or ordered goods or services from e-retailers in other EU countries [47]. Cross-border online purchases can be an indicator of the smooth functioning of a single market for e-commerce and the extent to which consumers make use of wider choices and lower prices [51]. Although most e-shoppers made online purchases from sellers in their own country, a rising trend has been observed for purchases from sellers in other EU member countries (from $25 \%$ in 2012 to 32\% in 2016), and from sellers outside the EU (from 13\% in 2012 to $20 \%$ in 2016) [47].

The EU countries most active in cross-border e-commerce are Luxembourg, Malta, and Cyprus [47]. This is because small countries do not have enough online shops to satisfy their consumers' needs. On the other side of this spectrum are Romania, Poland, and Germany, who are the least frequent cross-border e-buyers [47]. However, one should not confuse the share of cross-border buyers with the size of the market itself, which could be particularly misleading in the case of Germany.

Europeans choose cross-border e-commerce shopping mainly when the price is lower or when there is a promotion that removes the barrier or additional fees (duty, taxes, delivery), making the product available in their country more expensive [52]. Consumers want to have items ordered through cross-border e-commerce channels delivered to their home: $83 \%$ of Europeans declared using such delivery methods, while less than $10 \%$ preferred to collect their purchase from a shop and less than $5 \%$ preferred to go to a different collection point or to a Post Office [53]. One of the cross-border e-commerce barriers is language proficiency: $33 \%$ of EU consumers said they were able to purchase goods and services in another language, while $59 \%$ of retailers were prepared to handle transactions in more than one language [54]. Customers are also more willing to shop at retailers that offer payment in the customers' national currency [55]. A survey conducted for the European Commission in 2011 showed that $57 \%$ of Europeans did not purchase online via cross-border e-commerce channels because of concerns about returning goods and resolving issues with faulty products and uncertainty about the producer [56].

According to a recent survey made by Ecommerce Europe [18], the preferred strategy among retailers for international development consists of selling goods to consumers abroad directly from the company's country of origin. However, the main reason that companies are not selling cross-border is the overly restrictive regulations in other member states [57]. Also, different legal frameworks, complicated and expensive taxation systems, and logistics issues are still significant barriers for companies when selling cross-border in Europe [58]. However, member states adopt these basic regulations at different times and apply their own adjustments, leading to, for example, taxation being different in various member states [59].

In recent years, the European Commission has recognized that there are considerable barriers to cross-border online shopping. In 2009, one survey found that consumers could not complete $60 \%$ of 
cross-border online transactions because the retailer did not ship the product to the customer's country or did not offer adequate methods of cross-border payment [52]. Although these concerns are now less significant than before, customers are still concerned about delivery conditions, customer service, payment, and consumer rights [60].

\section{Hypothesis Development}

This section contains hypothesis development for six factors: Payments, currency, country recognition, delivery, security and shop-bots. All of them are provided previous research from the literature.

\subsection{Payments}

The popularity of credit cards, online banking, and online and mobile payments in the EU has created an environment that favors the development of e-commerce [35]. Prospective customers more frequently shop using their computers, smartphones, or tablets [43]. This research will check which payment options are available for the customers. Regarding payment, the following hypothesis is therefore proposed:

Hypothesis 1 (H1). E-tailers offer at least one internationally recognized payment option.

\subsection{Currency}

Regarding cross-border e-commerce payments, the decision on which payment methods are made available to potential clients may be affected by the currency selected for pricing [61]. In the case of a strategy of localization and adjustment of the website to particular markets handled by the market operator, all prices and costs connected with transaction handling should be consistently indicated in the target country's currency. The advantage of such solutions is a better localization and a greater impression of being a domestic entity, which entails being a safe purchase option from the point of view of prospective customers. Problems connected with a need to convert and update prices in relation to potential exchange-rate fluctuations are a disadvantage [56]. The decision regarding the currency in which one indicates prices and the strategy of localization of a website will indirectly affect the payment methods that are made available. This includes various payment systems that are most commonly handled by local banks or local mobile-network operators. Each available payment system has its unique features, technical solutions, and payment methods, and each offers selected languages and currencies. Moreover, each system is usually subject to the legal regulations of the country in which it operates. Currently, commonly recognized payment methods include credit cards and PayPal. Regarding currency, the following hypothesis is proposed:

Hypothesis 2 (H2). E-tailers offer payments in the currency of the consumer's country.

\subsection{Country Recognition}

A consumer who uses foreign online shops may be recognized through his or her IP address, so the seller may display the website in his or her language and display prices in the currency used in the consumer's country [61]. Moreover, the seller may initially, during the first visit to the website, ask for confirmation of whether the appropriate country for delivery and currency has been selected [46]. The IP address pool is assigned to Internet service providers who operate within each country, therefore, this method of determining a consumer's place of origin can be considered highly accurate. The following hypothesis is therefore proposed:

Hypothesis 3 (H3). E-tailers can recognize the country of origin of visiting customers. 


\subsection{Delivery}

Consumers who want to make a purchase from another country expect to be able to choose the delivery method, i.e., by national post or by a courier company. Also, the consumer would like to know when to expect the delivery of purchased goods and how long the transportation will take [62]. In the case of shipping between EU member states, consumers expect to receive the shipment within two to three days $[17,63]$. Consumers also expect to be able to track the shipment method and that the cost of shipping will be affordable. The following hypothesis is therefore proposed:

Hypothesis 4 (H4). E-tailers can deliver orders abroad.

\subsection{Security}

Currently, Internet browsers such as Chrome (v. 70+) and Firefox (v. 63+) warn consumers if the shop's website is not using HTTPS encryption [64]. In this way, Internet browser developers force online shops to use SSL certification. Sellers who have an SSL certificate assure consumers that their personal data, which they need to give to the shop when placing orders, will not be disclosed to third parties [43]. This applies to details of the person making the order, the place of delivery, and information regarding the selected payment method. The following hypothesis is therefore proposed:

Hypothesis 5 (H5). E-tailer shops use SSL certification.

\subsection{Shop-Bots}

In many European countries there are online shopping comparison websites [43]. They collect information about products and prices offered by online shops in a standardized format, usually in $\mathrm{XML}$, which they then display on their own website [36]. Examples of price comparison websites in various countries include: Ceneo in Poland; Idealo in Germany; PriceRunner in Denmark; and KuantoKusta in Portugal [37]. Price comparison websites may agree to include products from foreign online shops in their offer [38]. Usually, these websites require the ability to deliver to the country in which the website is operating, or at least for the shop's website to be available in English. Some price comparison websites, however, require that the shop's website be available also in the language of the country in which the price comparison websites operates. The following hypothesis is therefore proposed:

Hypothesis 6 (H6). E-tailer shops use foreign price comparison websites.

\section{Data and Results}

This section contains prepared data about e-tailers and results after checking the use of six factors.

\subsection{Data}

The research was conducted twice, in November 2017 and December 2018, to observe whether the characteristics of the e-tailers regarding the six factors had changed over this time period. The 30 Polish websites included in the study were visited using a web browser and accessed from Portugal and the United Kingdom. These 30 online Polish e-tailers are listed in the Appendix A and are the top 30 shops for household goods, based on traffic data obtained using the Semstorm tool [semstorm.com]. Semstorm estimates online traffic and measures the top 10 and top 50keywords in Google for each domain in Poland.

Many different stores operate in the digital market, however, for the purpose of this study, all 30 selected represent one industry sector, i.e., selling consumer electronics, mainly computers, smartphones, TVs, home cinema, and home appliances. Each e-tailer was analyzed in terms of its compliance with technical requirements facilitating selling goods abroad. The household goods 
industry was chosen for this study because it is a very competitive industry. Products are either to purchase in brick-and-mortar shops or in online stores. There are many e-tailers operating on this market, so it allows preparing a proper group for the study. The selected 30 e-tailers are the most visible in Google's search engine results page for Poland. The most visible, suggest also that they could be the most visited by consumers, however it is only an estimation of traffic, calculated by an external tool. These are not data coming from search engines. Some processes of gaining data were automated by using software for crawling websites. The screaming Frog SEO Spider was used to check the canonical version of each URL and check if the SSL security is enabled. Other factors were examined manually by visiting each e-tailers' website and checking its use of identified criteria. The following six criteria were tested: The use of electronic payments such as credit cards and micropayments, currency and price conversion, recognition of the country of the user's origin, the possibility of shipping orders abroad, safety in the form of HTTPS encryption, and the presence on foreign price comparison websites.

\subsection{Results}

In the first observation, the vast majority of e-tailers enabled payments using credit cards, which is the global standard for payments that are not bound by country borders. In the second observation, all of the studied e-tailers had enabled credit cards and micropayments, supporting H1. Unfortunately, none of the e-tailers offered currency conversion or language adjustment for customers from abroad. All prices were listed in Polish zloty and all pages were displayed in the Polish language only. Thus, $\mathrm{H} 2$ and $\mathrm{H} 3$ are not confirmed.

Deliveries to other countries were mentioned as an option on several shops' websites. It was assumed that if the e-tailer offered shipments using a globally recognized courier company, the shipment could be sent abroad using that company's services. The second condition in this assumption is that the terms of service do not state that delivery is for the country of origin only. Some of the shops did not use global courier companies at all. Many large e-tailers that also operate as large-format retail shops had developed their own delivery network that handled shipments within one country. Other e-tailers, however, only allowed a personal collection at the shop or at a collection point. In the first observation, $60 \%$ of e-tailers offered delivery abroad. In the second observation, $68 \%$ of e-tailers offered delivery abroad, confirming $\mathrm{H} 4$.

In the first observation, not all shops used SSL security certificates, despite popular Internet browsers displaying information that the connection was not secure at the point when the customer was entering details in the order form. The second observation, a year later, confirmed that all e-tailers had enabled HTTPS encryption and SSL certification, confirming H5. Since e-tailer shops were not translated into different languages, they were not on foreign price comparison websites. Thus, H6 was not confirmed.

The first observation in November 2017 revealed that 27 e-tailers enabled payments using electronic payment methods such as credit cards and micropayments. The remaining three e-tailers only allowed payments using a wire transfer or cash payments at the brick-and-mortar shop or at the collection point. None of the e-tailers enabled currency conversions from Polish zloty to a different currency, such as the euro. Moreover, none of the e-tailers adjusted to the language or the country of a user visiting the website from outside Poland. Deliveries to other countries were offered by 18 online e-tailers. A total of 25 e-tailers were using safe SSL protocol connections. None of the e-tailers were present on the foreign price comparison websites analyzed (KuantoKusta, Idealo, and PriceRunner).

The second observation, in December 2018, revealed different results. One of the e-tailers had ceased trading and two others had merged, leaving 28 e-tailers to analyze. All 28 e-tailers used an electronic payment method such as credit cards or micropayments. Still, however, none of the e-tailers could convert prices into other currencies, nor could they adjust the language to that of users from other countries. Deliveries to other countries were offered by 19 online e-tailers. All e-tailers had enabled HTTPS encryption using SSL certification. Again, none of the e-tailers were present on foreign price comparison websites. 
Answering to RQ1 on which key features are crucial for cross-border e-commerce, it is clear that delivery to another country is the most crucial. Other factors can be overridden by switching language using online translation services or currency conversion through PayPal or credit cards. Answering to RQ2 on how often e-tailers use the identified features, results showed that more than half e-tailers have at least few identified factors in use. There was no e-tailer, which was lacking in all of them.

\section{Conclusions}

This section contains contributions, practical implications, limitations and further research.

\subsection{Contributions}

In recent years, online transactions in cross-border e-commerce have become an essential part of the European e-market and have shown great potential. Because of some uncertainty in cross-border e-commerce, customers searched for factors that can reduce the risk of buying cross-border. E-tailers can show that they recognize and carefully treat customers from abroad. This study empirically explored which factors e-tailer shops are adopting to reveal their perceptions regarding customers' readiness to buy cross-border. There are three main findings. First, e-tailers do not consider the lack of currency conversion to be a barrier for customers as long as they offer well-known payment systems, like credit cards or PayPal. Second, e-tailers have been increasing website security since, due to recent changes in web browsers, customers expect to see typical signs of security like SSL certification and HTTPS encryption. Customers may refuse to use e-tailers who do not have such security measures. Third, some retailers do not want to deliver abroad and have stated in their terms of service that delivery is only to one country, despite the ability to deliver abroad. This finding could be extended to geographical-blocking (geo-blocking) behavior in future research. These findings have significant theoretical and practical implications.

This research can contribute to the literature on e-commerce behavior in three main ways. The first relates to the trust and security perspective. The consumers' environment is monitored across Europe and progress is tracked from a consumer's perspective. The latest report shows that consumer trust in online shopping has dramatically increased, especially in buying from other EU countries [65]. More than half of the consumers said that they felt confident about purchasing online goods and services from traders in another EU country. A lack of consumer trust in cross-border e-commerce has for many years been one of the most important demand-side barriers to tapping the full potential of the digital single market. This report shows that this is gradually becoming less of an obstacle. For years, customers have seen different security implementations on e-tailers' websites, from websites without any security solutions to those with full SSL security functions. Now customers are very aware of such things and expect to make purchases in a secure environment.

Second, price comparison websites that operate in countries other than that of the e-tailer shop are not used for increasing e-tailers' sales. Price comparison websites are, however, extremely popular in local, country-based e-markets since they use local language and currency, and do not tend to accept e-tailers from abroad. The results of the study suggest using price comparison websites for local markets. Third, e-tailers should provide clear information about delivery terms, options, and pricing for delivery abroad. If customers from abroad are attracted by the price of a product, the next step is to check that combining the cost of delivery to another country does not exceed the cost of buying a product in the local e-market. Thus, e-tailers should cooperate with globally recognized courier companies capable of delivering products abroad.

\subsection{Practical Implications}

This study also yields several direct managerial implications. First, e-tailers recognize the increasing importance of cross-border e-commerce sales. Even though the offer is only presented in the local currency and is not translated into another language, some e-tailers have set up dedicated departments for handling cross-border e-commerce. Such departments deal with dedicated sales for 
foreign customers, both retail and business, within the EU as well as processing orders for customers from outside the EU with the possibility of deducting VAT and shipping orders within the EU.

Second, in September 2016, Google announced that in the next version of Google Chrome, websites that do not use secure HTTPS and do not have an SSL certificate would be marked as "not secure" [64]. This update was launched in version 56 of Google Chrome, released in January 2017. This first concerned websites that had a login mechanism using a password and username, affecting all online e-tailers. Google has since announced further requirements for having an SSL certificate due in June 2018, where every page that does not have an SSL certificate is marked as "not secure." The first observation for the study took place over a year after the announcement about the increase of security requirements for websites. It is surprising that, at that time, five e-tailers did not have an SSL certificate and did not offer a secure HTTPS protocol. By the time of the second observation, all e-tailers had an SSL certificate. The browsers Mozilla Firefox and Safari also followed Google Chrome. This suggests that not having an SSL certificate probably scares online e-tailer store's customers, who receive a warning from the browser that the website is not secure.

Third, the obtained results are possibly strongly related to the selected industry, i.e., broadly understood consumer electronics and household goods. The margin for sold goods is usually low in this industry. Therefore, it may be concluded that purchasing a particular item abroad will not prove to be less expensive due to very similar prices in various countries. It is possible that the activity of shops in terms of cross-border sales is higher in the case of such industries as children's products and travel accessories, for which the margin is significantly higher. However, that would require further research. Consumers buy from abroad mainly because of lower price or the availability of goods. If the desired goods are available locally or the price is comparable, then they tend to buy locally.

\subsection{Limitations and Future Research}

This study has several limitations. First, the study was conducted in one industry only and the author only collected data from 30 e-tailers. However, the top 30 e-tailers with the highest visibility for the industry sector in the Google search engine were the subject of the study. The author acknowledges, however, that this sample size cannot adequately represent entire household-goods industry, as it does not reflect any lower-visibility e-tailers. To make the conclusions more convincing, data from more industries will need to be collected in the future. Second, observations were conducted only for one country, Poland. These observations, therefore, do not reflect e-tailers in other European countries. E-tailers from countries using a common currency like the Euro, or using a more popular language used by more than one nation, can more easily attract customers from abroad. Data reflecting more European countries needs to be collected to further investigate the role of the retailers' country of origin. Third, although each e-tailer was observed in terms of the same key features, there are still unobservable factors across e-tailers that might attract customers from abroad, such as brand recognition. Further studies will need to retrieve more data to address this issue.

One direction of the further studies concerns the issue of geo-blocking in cross-border e-commerce. Recently, the European Commission accepted regulations on geo-blocking and other forms of consumer discrimination based on nationality or place of residence. The regulations indicate specific situations in which the use of geographical blocking, i.e., the sale of products without delivery, or the sale of electronic goods is prohibited. The regulations also prohibit blocking access to websites and automatic redirections due to location. These practices, if not objectively justified, are set to be forbidden from December 3, 2018, the date of applicability of the EU regulation on geo-blocking. Further studies could examine which justifications allow e-tailers to geo-block customers and the scope of these regulations.

Cross-border e-commerce in the EU differs from the CBEC in USA or China. As the online stores and customers are from two different countries, the orders need to be sent from one country to another, thus crossing a border. This definition is applicable in the European Union (EU) [13], whereas in China cross-border e-commerce is often considered as a trade between different areas like North China and South China or pilot areas [66]. In North America, cross-border e-commerce is usually a name 
for a trade between USA and Canada [2]. These types of cross-border e-commerce could be another direction for future research.

Funding: This research received no external funding.

Conflicts of Interest: The authors declare no conflict of interest.

\section{Appendix A}

Below is a list of the top 30 Polish e-tailers in the households-good sector based on data from Semstorm [semstorm.com]. Semstorm collects data about the visibility of domains in google.pl. The 30 most visible were chosen for study.

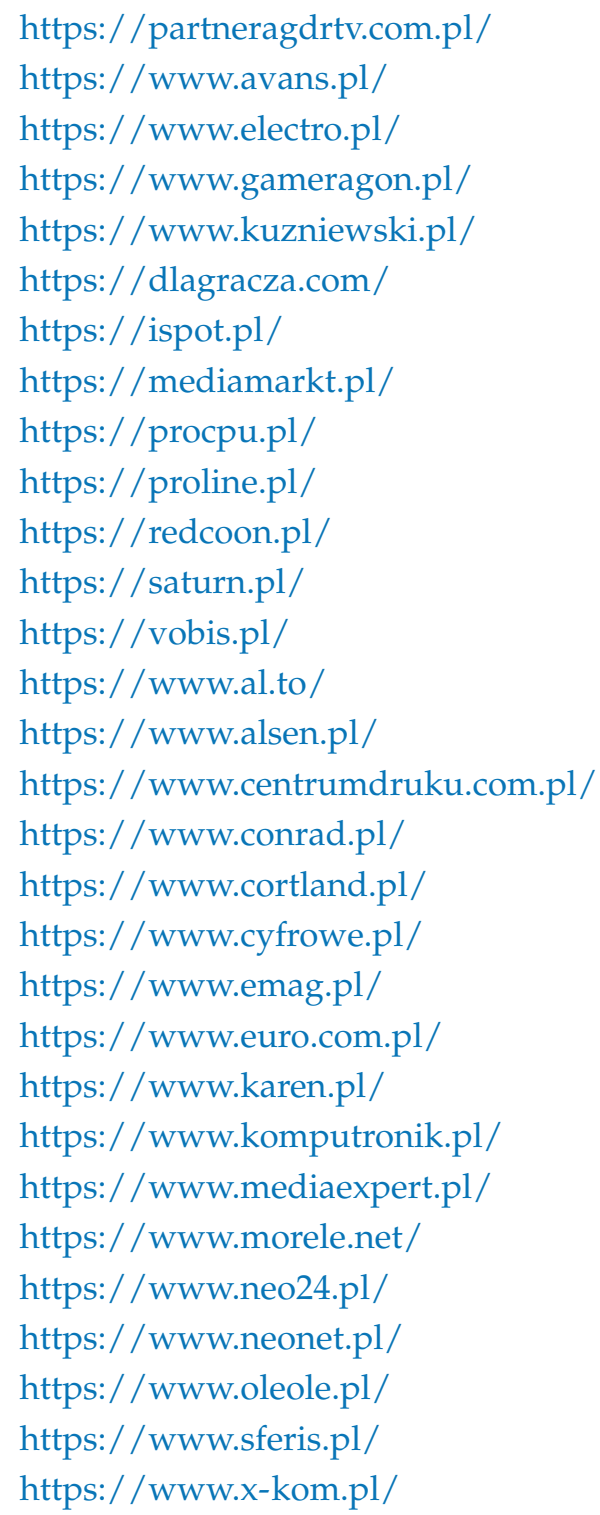

\section{References}

1. Kraemer, K.L.; Gibbs, J.; Dedrick, J. Impacts of Globalization on E-Commerce Use and Firm Performance: A Cross-Country Investigation. Inf. Soc. 2005, 21, 323-340. [CrossRef]

2. Gessner, G.H.; Snodgrass, C.R. Designing e-commerce cross-border distribution networks for small and medium-size enterprises incorporating Canadian and U.S. trade incentive programs. Res. Transp. Bus. Manag. 2015, 16, 84-94. [CrossRef] 
3. Hsiao, Y.-H.; Chen, M.-C.; Liao, W.-C. Logistics service design for cross-border E-commerce using Kansei engineering with text-mining-based online content analysis. Telemat. Inform. 2017, 34, 284-302. [CrossRef]

4. Su, W.; Wang, Y.; Qian, L.; Zeng, S.; Baležentis, T.; Streimikiene, D.; Su, W.; Wang, Y.; Qian, L.; Zeng, S.; et al. Creating a Sustainable Policy Framework for Cross-Border E-Commerce in China. Sustainability 2019, 11, 943. [CrossRef]

5. Wang, Y.; Wang, Y.; Lee, S. The Effect of Cross-Border E-Commerce on China's International Trade: An Empirical Study Based on Transaction Cost Analysis. Sustainability 2017, 9, 2028. [CrossRef]

6. Wang, Y.; Jia, F.; Schoenherr, T.; Gong, Y.; Wang, Y.; Jia, F.; Schoenherr, T.; Gong, Y. Supply Chain-Based Business Model Innovation: The Case of a Cross-Border E-Commerce Company. Sustainability 2018, 10, 4362. [CrossRef]

7. Zhong, X. Research on SWOT Analysis of Cross-border E-Commerce Logistics in China. Logist. Eng. Manag. 2016, 3, 2.

8. Xue, W.; Li, D.; Pei, Y. The Development and Current of Cross-border E-commerce. WHICEB 2016 Proc. 2016, 53, 131-138.

9. Nieradka, P.; Niedźwiecka, K. Cross-Border in the E-Commerce as Exemplified by the Baltic Countries. Int. J. Synerg. Res. 2017, 6, 163-174. [CrossRef]

10. de Souza, N.; von Wiese, I. European Union: EU adopts directive on e-commerce. Int. Financ. Law Rev. 2000, 19, 61-62.

11. Stare, M. The scope for E-Commerce in central and eastern European countries' services trade. Serv. Ind. J. 2003, 23, 27-42. [CrossRef]

12. Madhok, A. Cost, Value and Foreign Market Entry Mode: The Transaction and the Firm. Strateg. Manag. J. 1997, 18, 39-61. [CrossRef]

13. Gomez-Herrera, E.; Martens, B.; Turlea, G. The drivers and impediments for cross-border e-commerce in the EU. Inf. Econ. Policy 2014, 28, 83-96. [CrossRef]

14. European Commission. Digital Single Market; European Commission: Brussels, Belgium, 2015.

15. Ecommerce Europe. European B2C E-Commerce Report 2015; Ecommerce Europe: Brussels, Belgium, 2015.

16. Terzi, N. The impact of e-commerce on international trade and employment. Procedia Soc. Behav. Sci. 2011, 24, 745-753. [CrossRef]

17. International Post Corporation. Cross-Border e-Commerce Shopper Survey; International Post Corporation: Brussels, Belgium, 2017.

18. Ecommerce Europe. Cross-Border E-commerce Barometer 2016; Ecommerce Europe: Brussels, Belgium, 2016.

19. Patrikios, A. Resolution of Cross-Border E-Business Disputes by Arbitration Tribunals on the Basis of Transnational Substantive Rules of Law and E-Business Usages: The Emergence of the Lex Informatica. Univ. Toledo Law Rev. 2006, 38, 271-309.

20. Van den Heuvel, E. Online Dispute Resolution as a Solution to Cross-Border e-Disputes: An Introduction to ODR; University of Utrecht: Utrecht, The Netherlands, 2000.

21. Hörnle, J. Cross-Border Internet Dispute Resolution; Cambridge University Press: Cambridge, UK, 2009.

22. Calliess, G.P. Transnational Consumer Law: Co-Regulation of B2C-E-Commerce. In Responsible Business, Self-Governance and Law in Transnational Economic Transactions; Dilling, O., Martin, H., Winter, G., Eds.; Hart Publishing: Oxford, UK, 2008; pp. 225-258.

23. Stylianou, P. Online Dispute Resolution: The Case for a Treaty between the United States and the European Union in Resolving Cross-Border E-Commerce Disputes. Syracuse J. Int. Law Commer. 2008, 36, 117-143.

24. Edwards, L.; Wilson, C. Redress and Alternative Dispute Resolution in EU Cross-Border E-Commerce Transactions1. Int. Rev. Law Comput. Technol. 2007, 21, 315-333. [CrossRef]

25. European Commission. EUROBAROMETER Special Report 252: Consumer Protection in the Internal Market; European Commission: Brussels, Belgium, 2006.

26. Del Duca, L.F.; Rule, C.; Rogers, V. Designing a Global Consumer Online Dispute Resolution (ODR) System for Cross-Border Small Value - High Volume Claims - OAS Developments. Unif. Commer. Code Law J. 2010, 42, 221-256.

27. Del Duca, L.F.; Rule, C.; Loebl, Z. Facilitating Expansion of Cross-Border E-Commerce-Developing a Global Online Dispute Resolution System (Lessons Derived from Existing ODR Systems-Work of the United Nations Commission on International Trade Law). Penn State J. Law Int. Aff. 2012, 1, 58-61. [CrossRef] 
28. Cortés, P.; de la Rosa, F.E. Building a Global Redress System for Low-Value Cross-Border Disputes. Int. Comp. Law Q. 2013, 62, 407-440. [CrossRef]

29. Lin, A.J.; Li, E.Y.; Lee, S.-Y. Dysfunctional customer behavior in cross-border e-commerce: A Justice-affectbehavior model. J. Electron. Commer. Res. 2018, 19, 36-54.

30. Asosheh, A.; Shahidi-Nejad, H.; Khodkari, H. A Model of a Localized Cross-Border E-Commerce. Ibusiness 2012, 4, 136-145. [CrossRef]

31. Tan, Y.-H.; Thoen, W. Towards a generic model of trust in electronic commerce. Int. J. Electron. Commer. 2000, 5, 61-74.

32. Tian, R.G.; Lan, X. E-commerce Concerns: Cross-Cultural Factors in Internet Marketing. In Proceedings of the 2009 International Conference on Electronic Commerce and Business Intelligence, Beijing, China, 6-7 June 2009; pp. 83-86.

33. Sinkovics, R.R.; Yamin, M.; Hossinger, M. Cultural Adaptation in Cross Border E-Commerce: A Study of German Companies. J. Electron. Commer. Res. 2007, 8, 221-235.

34. Huang, Z.; Benyoucef, M. From e-commerce to social commerce: A close look at design features. Electron. Commer. Res. Appl. 2013, 12, 246-259. [CrossRef]

35. Curty, R.G.; Zhang, P. Website features that gave rise to social commerce: A historical analysis. Electron. Commer. Res. Appl. 2013, 12, 260-279. [CrossRef]

36. Tang, Z.; Smith, M.D.; Montgomery, A. The impact of shopbot use on prices and price dispersion: Evidence from online book retailing. Int. J. Ind. Organ. 2010, 28, 579-590. [CrossRef]

37. Dulleck, U.; Hackl, F.; Weiss, B.; Winter-Ebmer, R. Buying Online: An Analysis of Shopbot Visitors. Ger. Econ. Rev. 2011, 12, 395-408. [CrossRef]

38. Ellison, G.; Ellison, S.F. Search, Obfuscation, and Price Elasticities on the Internet. Econometrica 2009, 77, 427-452.

39. McCole, P.; Ramsey, E.; Williams, J. Trust considerations on attitudes towards online purchasing: The moderating effect of privacy and security concerns. J. Bus. Res. 2010, 63, 1018-1024. [CrossRef]

40. Kim, C.; Tao, W.; Shin, N.; Kim, K.-S. An empirical study of customers' perceptions of security and trust in e-payment systems. Electron. Commer. Res. Appl. 2010, 9, 84-95. [CrossRef]

41. Ming-Yen Teoh, W.; Choy Chong, S.; Lin, B.; Wei Chua, J. Factors affecting consumers' perception of electronic payment: An empirical analysis. Internet Res. 2013, 23, 465-485. [CrossRef]

42. Suchánek, P. Business Intelligence as a Support of E-Commerce Systems in Connection with Decision Making and Cross-Border Online Shopping. J. Appl. Econ. Sci. 2010, 5, 94-102.

43. Strzelecki, A.; Rizun, M. Consumers' Change in Trust and Security After Personal-data Leakage in Online Shopping. J. Retail. Consum. Serv.. under review.

44. Martens, B. What Does Economic Research Tell Us About Cross-Border E-Commerce in the EU Digital Single Market? Publications Office of the European Union: Luxembourg, 2013.

45. Kawa, A. Supply Chains of Cross-Border e-Commerce; Springer: Cham, Switzerland, 2017; pp. 173-183.

46. Talar, S. Cross-Border E-Commerce - Problems in Identification and Measurement. Contemp. Econ. 2017, 8, 13-27.

47. Eurostat 2017 E-commerce Statistics for Individuals. Available online: https://ec.europa.eu/eurostat/ statistics-explained/index.php/E-commerce_statistics_for_individuals (accessed on 20 February 2019).

48. Rădescu, O.-D. The Process of Globalization in the World Economy. J. Appl. Econ. Sci. 2008, 1, 69-73.

49. Mirdala, R. Financial Integration and Financial Deepening in the Selected European Transition Economies. J. Appl. Econ. Sci. 2008, 4, 419-433.

50. Van Heel, B.; Lukic, V.; Leeuwis, E. Cross-Border E-Commerce Makes the World Flatter; The Boston Consulting Group: Boston, MA, USA, 2014.

51. Lim, K.H.; Leung, K.; Sia, C.L.; Lee, M.K. Is eCommerce boundary-less? Effects of individualism-collectivism and uncertainty avoidance on Internet shopping. J. Int. Bus. Stud. 2004, 35, 545-559. [CrossRef]

52. Hunter, J.; Wilson, M. Cross-Border Online Shopping Within the Eu Learning from Consumer Experiences; ANEC: Brussels, Belgium, 2015.

53. European Commission. Retailers' Attitudes towards Cross-Border Trade and Consumer Protection 2016; European Commission: Brussels, Belgium, 2016.

54. McDermott, K. Key Business Drivers and Opportunities in Cross-Border Ecommerce; Payvision BV: Amsterdam, The Netherlands, 2015. 
55. Perrault, A.; Gregory, V. Think Global, Act Local: The Challenges of Taking the Website Global. Int. J. Spec. Libr. 2000, 34, 227-237.

56. Kawa, A.; Zdrenka, W. Conception of Integrator in Cross-Border E-Commerce. Logforum 2016, 12, 63-73. [CrossRef]

57. Meltzer, J.P. The Internet, Cross-Border Data Flows and International Trade. Asia Pacific Policy Stud. 2015, 2, 90-102. [CrossRef]

58. Ding, F.; Huo, J.; Campos, J.K. The Development of Cross Border E-commerce. Adv. Econ. Bus. Manag. Res. 2017, 37, 370-383.

59. Gałuszka, J. How to Tax E-Commerce-Gobal or National Problem? Stud. Ekon. 2013, 150, 193-202.

60. Cardona, M.; Duch-Brown, N.; Martens, B. Consumer Perceptions of (Cross-Border) eCommerce in the EU Digital Single Market; Joint Research Centre of the European Commission: Barcelona, Catalonia, 2015.

61. Kalinić, Z.; Ranković, V.; Kalinić, L. Challenges in Cross-border E-commerce in the European Union. Zesz. Nauk. Uniw. Ekon. w Krakowie 2018, 5, 159-170. [CrossRef]

62. Ducret, R. Parcel deliveries and urban logistics: Changes and challenges in the courier express and parcel sector in Europe-The French case. Res. Transp. Bus. Manag. 2014, 11, 15-22. [CrossRef]

63. Kim, T.Y.; Dekker, R.; Heij, C. Cross-Border Electronic Commerce: Distance Effects and Express Delivery in European Union Markets. Int. J. Electron. Commer. 2017, 21, 184-218. [CrossRef]

64. Schechter, E. Moving towards a More Secure Web. Available online: https:/ /security.googleblog.com/2016/ 09/moving-towards-more-secure-web.html (accessed on 20 February 2019).

65. European Commission. Consumer Conditions Scoreboard; European Commission: Brussels, Belgium, 2017.

66. Lu, B.; Wang, H. Research on the Competitive Strategy of Cross-Border E-Commerce Comprehensive Pilot Area Based on the Spatial Competition. Sci. Program. 2016, 2016, 1-9. [CrossRef]

(C) 2019 by the author. Licensee MDPI, Basel, Switzerland. This article is an open access article distributed under the terms and conditions of the Creative Commons Attribution (CC BY) license (http:/ / creativecommons.org/licenses/by/4.0/). 